\title{
Maize Response, Changes in Soil Available Nutrients and Microbial Population as Influenced by Brewery Wastewater Irrigation
}

\author{
B.N. Manjunatha ${ }^{1^{*}}$, S. Bhaskar ${ }^{2}$ and H.S. Shivaramu ${ }^{3}$ \\ ${ }^{1}$ Dryland Agriculture, GKVK, UAS, Bengaluru-560 065, Karnataka, India \\ ${ }^{2}$ Agronomy, Agro-forestry and Climate Change, ICAR, New Delhi-110 012, India \\ ${ }^{3}$ AICRP on Agrometerology, GKVK, UAS, Bengaluru-560 065, Karnataka, India \\ *Corresponding author
}

\section{A B S T R A C T}

\begin{tabular}{|l|}
\hline Ke y w o r d s \\
Brewery \\
wastewater, \\
Maize, Yield, \\
Soil properties \\
and Microbial \\
population \\
\hline Article Info \\
\hline Accepted: \\
25 March 2017 \\
Available Online: \\
10 April 2017 \\
\hline
\end{tabular}

\section{Introduction}

In arid and semi-arid regions, wastewater is considered a valuable source of irrigation water and a fertilizing material. (AI-Rashed et al., 2000; Tarchitsky et al., 1999). Pollution of soil and water bodies is a serious problem ever since man started disposing sewage and industrial effluents into water bodies and on land.

Their efficient use is indispensable for sustainable agriculture in view of the shrinking land, man and water, man ratios, increasing fertilizer prices, haunting energy crisis, wide spread pollution and fast degradation and depletion of natural resources.
When wastewater is used properly for irrigation it is considered an environmentally sound disposal practice (Papadopoulos, 1995). Such a proper use can relatively minimize pollution of the ecosystem which otherwise would be contaminated by direct disposal of wastewater into surface or ground water (Hespanhol, 1990; Gori et al., 2000). Wastewater contains huge quantity of nutrients which are essential for plants growth and development and it also adds the organic carbon to the soil. Thus leads to use as fertilizer and improves soil fertility and productivity. Application of 0, 25, 50, 75 and $100 \%$ effluent decreased the organic carbon, $\mathrm{N}, \mathrm{P}, \mathrm{Na}$, and $\mathrm{Mg}$ concentration in the soil 
while $\mathrm{K}, \mathrm{Ca}, \mathrm{C} / \mathrm{N}$ ratio, soil $\mathrm{pH}$ were increased. There were no changes observed in the soil textural class. The growth of maize plant as well as chlorophyll content was enhanced with brewery effluent treatments when compared with the control (Orhue et al., 2005). Combined use of brewery waste water sludge and two different types of composts increased the germination per cent and dry matter yield of chili and pumpkin when compared to brewery wastewater sludge or compost alone. Brewery wastewater sludge has recorded higher water retention capacity when compared to compost. Thus, there is a need to develop eco-friendly measures to utilize these liquid wastes profitably (Kangachandran and Jayaratne, 2006). In addition to fertilizer source also serves the problem of disposal and reduces scarcity of water to agriculture in peri-urban areas.

Several researchers has been studied the use of wastewater irrigation on different crops in different weather conditions and site locations. Campbell et al., (1983) stated that a weekly application of $25 \mathrm{~mm}$ of wastewater was enough to supply $40-80 \%$ of the corn $\mathrm{N}$ requirements and all $\mathrm{P}$ needed. Other researchers reported similar results (Elliot and Stevenson, 1997). Ouazzani et al., (1996) found that meadows irrigated with wastewater received $\mathrm{N}$ and $\mathrm{P}$ in amount equivalent or superior to the recommended dose of fertilizers for meadows. Jamjoum and Khattari (1986) found that corn yield was increased by irrigation with wastewater and they attributed this increase to the enhancement of nutrient uptake and improvement of the physical properties of the soil. Keeping this the background use of brewery wastewater irrigation on maize and soil properties have been conducted and results of the experiment is presented below.

\section{Material and Methods}

Field experiments were conducted at United
Breweries (UB), Nelamangala and Zonal Agricultural Research Station, UAS, GKVK, Bengaluru located in Eastern Dry Zone of Karnataka and situated at $12^{\circ} 11^{\prime}$ North latitude $76^{\circ} 69^{\prime}$ East longitude with an altitude of 980 meters above mean sea level during 2009 and 2010. The soils of the experimental site at UB Ltd, Nelamangala were sandy loam in texture and soil was neutral in reaction $(\mathrm{pH}$ 7.19). Electrical conductivity of soil was 0.18 $\mathrm{dSm}^{-1}$. The organic carbon content was 0.58 per cent. The available nitrogen was medium (315.8 $\left.\mathrm{kg} \mathrm{ha}^{-1}\right)$, phosphorus was low (13.17 $\mathrm{kg} \mathrm{ha}^{-1}$ ) and potassium (103.4 $\mathrm{kg} \mathrm{ha}^{-1}$ ) was low. At ZARS, GKVK, the soil was sandy clay loam in texture, acidic in reaction $(\mathrm{pH}$ 6.4) and electrical conductivity of $0.15 \mathrm{dSm}^{-1}$. The organic carbon content was 0.56 per cent. The available nitrogen was low (221.34 $\left.\mathrm{kg} \mathrm{ha}^{-1}\right)$, phosphorus was low (19.13 $\left.\mathrm{kg} \mathrm{ha}^{-1}\right)$ and potassium $\left(265.25 \mathrm{~kg} \mathrm{ha}^{-1}\right)$ was medium. The experiments were laid out in randomized complete block design (RCBD) consisting of nine treatments and replicated thrice. The hybrid Maize (NAH-2049) is used as test crop. The treatment details and corresponding symbol used in the study are as follows $\mathrm{T}_{1}$ : fresh water $+\mathrm{RDF}, \mathrm{T}_{2}$ : RDN through UBWW as $50 \%$ basal and $50 \%$ in three irrigations, $\mathrm{T}_{3}$ : RDN through UBWW as $25 \%$ basal and $75 \%$ in three irrigations, $\mathrm{T}_{4}: \mathrm{RDN}$ through TBWW as $50 \%$ basal and $50 \%$ in three irrigations, $\mathrm{T}_{5}$ : RDN through TBWW as $25 \%$ basal and $75 \%$ in three irrigations, $\mathrm{T}_{6}: 150 \%$ RDN through UBWW as $50 \%$ basal and 50 $\%$ in three irrigations, $\mathrm{T}_{7}: 150 \% \mathrm{RDN}$ through UBWW as $25 \%$ basal and $75 \%$ in three irrigations, $\mathrm{T}_{8}: 150 \%$ RDN through TBWW as $50 \%$ basal and $50 \%$ in three irrigations, $\mathrm{T}_{9}: 150 \% \mathrm{RDN}$ through TBWW as $25 \%$ basal and $75 \%$ in three irrigations. The experimental results were statistically scrutinized as suggested by Panse and Sukhatme (1985). The critical difference was worked out at 5 per cent (0.05) probability levels. 
Note

RDF- Recommended dose of fertilizers, RDN- Recommended dose of nitrogen, UBWW- Untreated brewery wastewater, TBWW- Treated brewery wastewater

\section{Results and Discussion}

The grain yield depends on the synthesis and accumulation of photosynthates and their distribution among various plant parts. The synthesis, accumulation and translocation of photosynthates depend upon efficient photosynthetic structure as well as the extent of translocation into sink (grains) and also on plant growth and development during early stages of crop growth. The production and translocation of synthesized photosynthates depends upon mineral nutrition supplied either by soil or through foliar application. Most of the photosynthetic pathways are dependent on enzymes and co-enzymes which are synthesized from mineral elements such as nitrogen, phosphorus and potassium.

Nitrogen improves plant growth and productivity by having direct effect on the metabolism of plants. Nitrogen is usually applied through organic or inorganic sources. Cereals consume more amount of nitrogen when compared to other major nutrients, as it is essential in almost all the metabolic processes. The time of application as well as the stage of plant growth determines the uptake and translocation of nitrogen. Phosphorus and potassium supply in early vegetative stage has greater influence on yield of crops. Hence, major nutrients play a vital role in growth, yield and quality of crops.

In field experiment of maize yields differed slightly during first (2009) and second (2010) year of experiments, but the pattern of response to brewery wastewater used for irrigation was similar in both the years. Therefore, only pooled data of the two years are presented (Table 1).

\section{Grain and stover yield}

In the present study, pooled results revealed that grain and stover yield of maize differed significantly due to brewery wastewater irrigation. Application of $150 \%$ RDN through TBWW as 50\% basal and 50\% in three irrigations recorded highest grain and stover yield (39.6 and $69.9 \mathrm{q} \mathrm{ha}^{-1}$, respectively) compared to all the other treatments. However, it was on par with $\mathrm{T}_{6}$ (39.1 and 69.2 $\mathrm{q} \mathrm{ha}^{-1}$, respectively), $\mathrm{T}_{9}$ (38.2 and $67.6 \mathrm{q} \mathrm{ha}^{-1}$, respectively) and $\mathrm{T}_{7}\left(37.8\right.$ and $66.3 \mathrm{q} \mathrm{ha}^{-1}$, respectively). Increase in grain yield of maize is due to higher plant height, more number of leaves, leaf area, leaf area index, total dry matter accumulation, number of cobs plant ${ }^{-1}$, more cob length, number of rows $\mathrm{cob}^{-1}$ and test weight observed in this treatment. These results are in conformity with the findings of Efstathios et al., (2009) and Moazzama et al., (2010) revealed that treated urban wastewater effectively increased the yield of cultivated forage crop species due to the nutritive value of the wastewater, although the differences were not statistically significant.

Field experiments at Nigeria agricultural farm during 2006 and 2007 results revealed that application of palm oil mill effluent in maize as organic fertilizer increased dry matter, grain yield, stover yield and grain NPK content (Nwoko, 2010) and Selim (2008), reported that crops irrigated with secondary treated wastewater performed equally well or significantly better than those irrigated with canal water. Seed and biological yields of plants given wastewater in the absence of chemical fertilizers were nearly equal to those of plants given the recommended dose of chemical fertilizers, indicating that wastewater could provide an adequate amount of $\mathrm{N}, \mathrm{P}$ and $\mathrm{K}$ to cover crop requirements at different growth stages. During 2013, Senthilraja et al., revealed that brewery 
wastewater application produced significantly more dry matter than the other treatments in Maize, Sunflower and Sesame crops. The higher concentration of brewery wastewater irrigation significantly increases the dry matter production such effect was more pronounced in maize.

\section{Changes in soil properties}

After harvest of maize crop soil samples were analyzed for following parameters like $\mathrm{pH}$, EC, available nitrogen, phosphorus and potassium results presented below (Table 2).

Soil reaction did not differ significantly due to brewery wastewater irrigation to maize. However, marginal increase in $\mathrm{pH}$ was observed in treatments which received treated brewery wastewater irrigation. Salt content in soil differed significantly due to brewery wastewater irrigation. Application of treated brewery wastewater marginally increased the EC after the harvest of maize when compared to EC of soil which received freshwater plus recommended dose of fertilizers and also untreated brewery wastewater EC value of soil. This is attributed to the use of treated brewery wastewater containing appreciable amount of salts for irrigation to soil has enhanced the EC. The results are in accordance with Hati et al., (2005) and Bhagyalakshmi (2009) reported increased $\mathrm{pH}$ and electrical conductivity of soil with usage of spent wash.

Available $\mathrm{N}$ in soil differed significantly due to brewery wastewater irrigation. Application of $150 \%$ RDN through UBWW as $25 \%$ basal and $75 \%$ in three irrigations recorded higher available $\mathrm{N}$ in soil followed by $\mathrm{T}_{9}, \mathrm{~T}_{6}$ and $\mathrm{T}_{7}$ (186.3, 185.4, 184.0 and $183.6 \mathrm{~kg} \mathrm{ha}^{-1}$, respectively) compared to all the other treatments (Fig. 1). This might be due to slow release of $\mathrm{N}$ from brewery wastewater which decreased the $\mathrm{N}$ loss from soil and maintained higher $\mathrm{N}$ potential throughout the plant growth period. These improvements in $\mathrm{N}$ uptake could be supported by the studies of Sukanya and Meli (2003) who observed that spentwash consisting of $\mathrm{N}$ chiefly in organic colloidal form functioned as slow releasing fertilizer upon application to soil. Vijay Krishna (2005) found that raw coffee pulp effluent irrigation recorded higher soil available nitrogen (155 kg ha-1) as compared to freshwater irrigation + RDF (83.62 $\left.\mathrm{kg} \mathrm{ha}^{-1}\right)$.

Available $\mathrm{P}$ in soil varied significantly due to application of brewery wastewater irrigation and freshwater plus recommended dose of fertilizers (Fig. 1). This was due to organically bond $\mathrm{P}$ in brewery wastewater, which takes some time to get decomposed into available form. Zalawadia et al., (1997) reported that two thirds of the phosphorus in spent wash was in organic form. Some researchers recorded improved available $\mathrm{P}$ in soil with application of spent wash.

Available potassium content of soil differed significantly due to brewery wastewater irrigation. Maximum soil available $\mathrm{K}$ was accumulated in treatments receiving brewery wastewater.

This is due to the fact that, brewery wastewater containing substantial amount of $\mathrm{K}(0.02 \%)$ is mostly in ionic form and that becomes immediately available to plants. The results obtained from the present study are in conformity with the findings of Patak et al., (1999) observed appreciable increase in available potassium status in soil irrigated with distillery effluent. Basavalingaiah et al., (2009) reported that soil available potassium was significantly increased due to raw coffee effluent irrigation (461.4 $\mathrm{kg} \mathrm{ha}^{-1}$ ) as compared to freshwater irrigation $\left(286.7 \mathrm{~kg} \mathrm{ha}^{-1}\right)$. 
Table.1 Grain and stover yield of maize as influenced by brewery wastewater irrigation

\begin{tabular}{|c|ccccccc|}
\hline \multirow{2}{*}{ Treatments } & \multicolumn{3}{|c}{ Grain yield $\left(\mathbf{q ~ h a} \mathbf{~}^{-\mathbf{1}}\right)$} & & \multicolumn{3}{c|}{ Stover yield $\left(\mathbf{q} \mathbf{~ h a}^{\mathbf{- 1}}\right)$} \\
\cline { 2 - 4 } \cline { 6 - 8 } & $\mathbf{2 0 0 9}$ & $\mathbf{2 0 1 0}$ & Pooled & & $\mathbf{2 0 0 9}$ & $\mathbf{2 0 1 0}$ & Pooled \\
\hline $\mathbf{T}_{\mathbf{1}}$ & 27.0 & 33.9 & 30.5 & & 45.8 & 56.1 & 51.0 \\
$\mathbf{T}_{\mathbf{2}}$ & 30.2 & 34.4 & 32.3 & & 48.7 & 58.4 & 53.5 \\
$\mathbf{T}_{\mathbf{3}}$ & 27.6 & 33.7 & 30.7 & & 46.9 & 57.3 & 52.1 \\
$\mathbf{T}_{\mathbf{4}}$ & 30.4 & 34.6 & 32.5 & & 51.7 & 58.6 & 55.2 \\
$\mathbf{T}_{\mathbf{5}}$ & 28.6 & 33.7 & 31.2 & & 50.8 & 58.3 & 54.6 \\
$\mathbf{T}_{\mathbf{6}}$ & 35.7 & 42.5 & 39.1 & & 64.5 & 73.9 & 69.2 \\
$\mathbf{T}_{\mathbf{7}}$ & 35.0 & 40.6 & 37.8 & & 61.4 & 71.2 & 66.3 \\
$\mathbf{T}_{\mathbf{8}}$ & 36.7 & 42.6 & 39.6 & & 65.1 & 74.6 & 69.9 \\
$\mathbf{T}_{\mathbf{9}}$ & 35.5 & 40.9 & 38.2 & & 63.3 & 71.9 & 67.6 \\
\hline S. $\mathbf{E m} \pm$ & $\mathbf{1 . 0 1}$ & $\mathbf{1 . 9 7}$ & $\mathbf{1 . 5 4}$ & & $\mathbf{2 . 0 2}$ & $\mathbf{3 . 4 4}$ & $\mathbf{3 . 0 0}$ \\
C. D. at 5\% & $\mathbf{3 . 0 5}$ & $\mathbf{5 . 9 2}$ & $\mathbf{4 . 4 3}$ & & $\mathbf{6 . 0 7}$ & $\mathbf{1 0 . 3 0}$ & $\mathbf{8 . 6 3}$ \\
\hline
\end{tabular}

Note:

$\mathrm{T}_{1}-$ Fresh water $+\mathrm{RDF}$

$\mathrm{T}_{3}-\mathrm{RDN}$ through UBWW as $25 \%$ basal and $75 \%$ in three irrigations

$\mathrm{T}_{5}-\mathrm{RDN}$ through TBWW as $25 \%$ basal and $75 \%$ in three irrigations

$\mathrm{T}_{7}-150 \%$ RDN through UBWW as $25 \%$ basal and $75 \%$ in three irrigations

$\mathrm{T}_{9}-150 \% \mathrm{RDN}$ through TBWW as $25 \%$ basal and $75 \%$ in three irrigations

Recommended dose of fertilizer: $150: 75: 40 \mathrm{~kg} \mathrm{~N}, \mathrm{P}_{2} \mathrm{O}_{5}$ and $\mathrm{K}_{2} \mathrm{O}$ ha $^{-1}$ for $\mathrm{T}_{1}$
$\mathrm{T}_{2}$ - RDN through UBWW as $50 \%$ basal and $50 \%$ in three irrigations

$\mathrm{T}_{4}$ - RDN through TBWW as $50 \%$ basal and $50 \%$ in three irrigations

$\mathrm{T}_{6}-150 \%$ RDN through UBWW as $50 \%$ basal and $50 \%$ in three irrigations

$\mathrm{T}_{8}-150 \%$ RDN through TBWW as $50 \%$ basal and $50 \%$ in three irrigations

UBWW- Untreated Brewery Wastewater, TBWW- Treated

Brewery Wastewater

FYM: $10 \mathrm{t} \mathrm{ha}^{-1}$ common for all the treatments

Table. $2 \mathrm{pH}$, EC, available nitrogen, phosphorous and potassium as influenced by brewery wastewater irrigation

\begin{tabular}{|c|c|c|c|c|c|}
\hline \multirow{2}{*}{ Treatments } & \multirow{2}{*}{$\mathbf{p H}$} & \multirow{2}{*}{$\mathbf{E C}$} & \multicolumn{3}{|c|}{ Kg ha $^{\mathbf{- 1}}$} \\
\cline { 4 - 6 } & & & Av. $\mathbf{~}$ & Av. $\mathbf{P}$ & Av. $\mathbf{~}$ \\
\hline $\mathbf{T}_{\mathbf{1}}$ & 7.38 & 0.18 & 168.7 & 21.8 & 144.7 \\
$\mathbf{T}_{\mathbf{2}}$ & 6.44 & 0.17 & 177.2 & 27.8 & 146.7 \\
$\mathbf{T}_{\mathbf{3}}$ & 6.40 & 0.15 & 178.6 & 28.4 & 147.6 \\
$\mathbf{T}_{\mathbf{4}}$ & 7.41 & 0.22 & 177.3 & 27.0 & 146.5 \\
$\mathbf{T}_{\mathbf{5}}$ & 7.40 & 0.22 & 178.1 & 28.4 & 147.4 \\
$\mathbf{T}_{\mathbf{6}}$ & 6.38 & 0.19 & 184.0 & 33.3 & 151.9 \\
$\mathbf{T}_{\mathbf{7}}$ & 6.39 & 0.18 & 186.3 & 35.0 & 152.3 \\
$\mathbf{T}_{\mathbf{8}}$ & 7.37 & 0.24 & 183.6 & 33.3 & 151.1 \\
$\mathbf{T}_{\mathbf{9}}$ & 7.38 & 0.24 & 185.4 & 33.9 & 152.3 \\
\hline S. Em $\mathbf{E m}$ & $\mathbf{0 . 0 6}$ & $\mathbf{0 . 0 3}$ & $\mathbf{1 . 5 5}$ & $\mathbf{1 . 5 7}$ & $\mathbf{1 . 0 8}$ \\
C. D. at 5\% & $\mathbf{0 . 1 7}$ & $\mathbf{0 . 0 9}$ & $\mathbf{4 . 4 7}$ & $\mathbf{4 . 5 1}$ & $\mathbf{3 . 1 1}$ \\
\hline
\end{tabular}

Note:

$\mathrm{T}_{1}-$ Fresh water $+\mathrm{RDF}$

$\mathrm{T}_{3}-\mathrm{RDN}$ through UBWW as $25 \%$ basal and $75 \%$ in three irrigations

$\mathrm{T}_{5}-\mathrm{RDN}$ through TBWW as $25 \%$ basal and $75 \%$ in three irrigations

$\mathrm{T}_{7}-150 \%$ RDN through UBWW as $25 \%$ basal and $75 \%$ in three irrigations

$\mathrm{T}_{9}-150 \% \mathrm{RDN}$ through TBWW as $25 \%$ basal and $75 \%$ in three irrigations

Recommended dose of fertilizer: $150: 75: 40 \mathrm{~kg} \mathrm{~N}, \mathrm{P}_{2} \mathrm{O}_{5}$ and $\mathrm{K}_{2} \mathrm{O}$ ha $^{-1}$ for $\mathrm{T}_{1}$
$\mathrm{T}_{2}$ - RDN through UBWW as $50 \%$ basal and $50 \%$ in three irrigations

$\mathrm{T}_{4}$ - RDN through TBWW as $50 \%$ basal and $50 \%$ in three irrigations

$\mathrm{T}_{6}-150 \%$ RDN through UBWW as $50 \%$ basal and $50 \%$ in three irrigations

$\mathrm{T}_{8}-150 \%$ RDN through TBWW as $50 \%$ basal and $50 \%$ in three irrigations

UBWW- Untreated Brewery Wastewater, TBWW- Treated Brewery Wastewater

FYM: $10 \mathrm{tha}^{-1}$ common for all the treatments 
Fig.1 Available nitrogen, $\mathrm{P}_{2} \mathrm{O}_{5}$ and $\mathrm{K}_{2} \mathrm{O}\left(\mathrm{kg} \mathrm{ha}^{-1}\right)$ as influenced by brewery wastewater irrigation in soil after harvest of maize

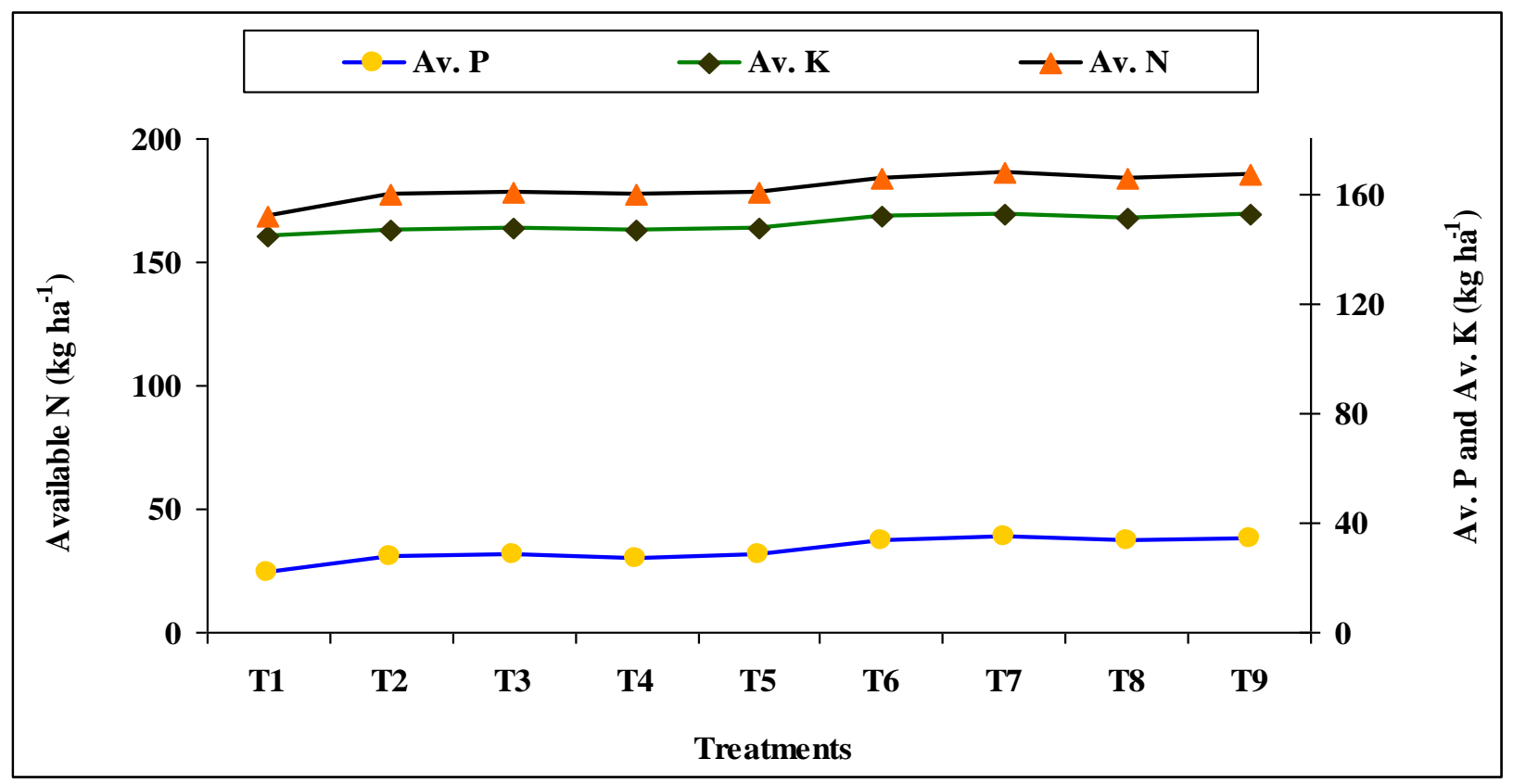

Fig.2 Soil microbial population as influenced by brewery wastewater irrigation on maize

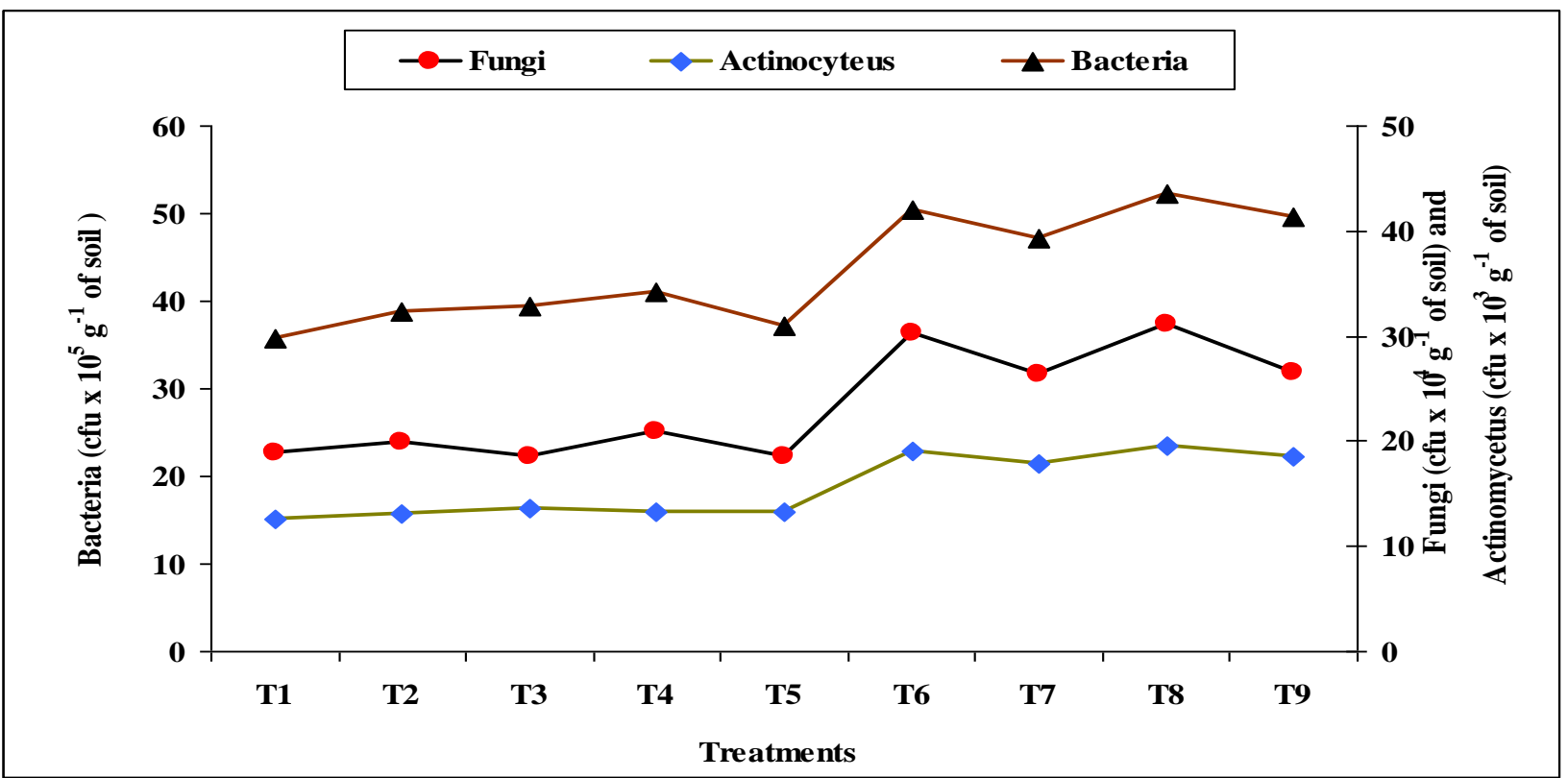

Soil beneficial microorganisms

The soil beneficial microorganisms such as soil fungi, bacteria, actinomycetes, $\mathrm{N}$-fixers and P-solublizer populations differed significantly due to brewery wastewater irrigation (Fig. 2). The application of $150 \%$ RDN through TBWW as 50\% basal and 50\% in three irrigations recorded significantly highest fungi, bacterial and actinomycetes 
$\left(52.19 \mathrm{cfu} \times 10^{5}, 31.19 \mathrm{cfu} \times 10^{4}\right.$ and $19.58 \mathrm{cfu}$ $\mathrm{x} 10^{3}$, respectively) followed by $150 \% \mathrm{RDN}$ through UBWW as $50 \%$ basal and $50 \%$ in three irrigations $\left(50.51 \mathrm{cfu} \times 10^{5}, 30.35 \mathrm{cfu}\right.$ $\times 10^{4}$ and $19.08 \mathrm{cfu} \times 10^{3}$, respectively), $150 \%$ RDN through TBWW as $25 \%$ basal and $75 \%$ in three irrigations $\left(49.53 \mathrm{cfu} \times 10^{5}, 26.57 \mathrm{cfu}\right.$ $\times 10^{4}$ and $18.60 \mathrm{cfu} \times 10^{3}$, respectively) and $150 \%$ RDN through UBWW as $25 \%$ basal and $75 \%$ in three irrigations (47.19 $\mathrm{cfu} \times 10^{5}$, $26.40 \mathrm{cfu} \times 10^{4}$ and $17.78 \mathrm{cfu} \times 10^{3}$, respectively) compared to all the other treatments

Soil $\mathrm{pH}$ above neutral range favours the growth and multiplication of bacteria. Similar results have been observed by Srinivasamurthy et al., (2008) indicated that there was no adverse effect of spent wash applied as ferti-irrigation to maize crop on the soil microbial population. On the other hand, brewery wastewater applied plots had slightly higher population of microbial population (Fungi, Bacteria and Actinomycetes). This is a positive aspect and is in favour of utilization of brewery wastewater as a source of nutrients in crop production. Jnaneesha (2008) reported that soil fungi, bacterial and actinomycetes population were increased due to application of coffee pulp effluent. The results are in conformity with the findings of Ekhaise and Anyasi (2005) were analyzed brewery wastewater for total microbial population, which had values ranging from $1.0 \times 10^{3}$ to $4.8 \times 10^{3} \mathrm{cfu} \mathrm{ml}^{-1}$ and $1.3 \times 10^{7}$ to $5.7 \times 10^{7} \mathrm{cfu}$ $\mathrm{ml}^{-1}$ for the fungal and bacterial isolates respectively. Total coli-form counts ranged from $4.3 \times 10 \mathrm{MPN} / 100 \mathrm{ml}$ to $38 \times 10$ MPN/100ml. Microorganisms isolated include Sacchromyces cereviceae, Aspergillus niger, Penicillium sp., Geotrichum sp. Candida sp., Proteus sp. Staphylococcus sp, Escherichia coli, Streptococcus faecalis and Bacillus sp. Shang Ran (2003) observed that increasing the ratio of wastewater concentration continuously increasing the quantities of bacteria, actionomycetes, aerobic cellulose-decomposing bacteria, nitric acid bacteria, nitrous acid bacteria, free-living nitrogen-fixing bacteria and decreasing later. At higher wastewater concentration the nutrient components in sewage could stimulate fungus, nitrifying bacteria, denitrifying bacteria and some anaerobic bacteria to propagate. Irrigation concentration of brewery wastewater sludge with the optimum ratio of water to sewage of i.e. 2:1 or 1:2 found best and the higher sewage concentration would be disadvantageous to plant growth.

\section{References}

Ai-Rashed, M.F. and Sherif, M.M. Water resources in the GCC countries: an overview. Water Resour. Mgt. 2000, 14 (1), 59-73.

Basavalingaiah, Bhaskar, S., Girisha. H. C. and Srinivasamurthy, c. A., 2009, Utilization of coffee pulp effluent as a source of irrigation on growth, yield, quality of baby corn and chemical properties of soil. National Seminar on Sustainable Waste Management, Mangalore, P. 52.

Bhagyalaksmi, 2009, Studies on the effect of industrial effluent on soil properties and crop growth. Ph.D., Thesis, Univ. Agric. Sci., Bengaluru.

Campbell, W. F. Miller, R. W. Screeg, T. M., and Alfalfa, 1983, Sweet corn and wheat responses to long term application of municipal wastewater to crop land. J. Environ. Qual. 2, 243249.

Efstathios, T., Martha, L., Ioannis, P., Thomas, S., Fokion, P., Maria, T. and Paraskevi, M., George, V., 2009, The effect of treated urban wastewater on soil properties, plant tissue composition and biomass productivity in berseem clover and corn. J. Food Agric. Envt., 7(3-4):782-786. 
Ekhaise, F. O. and Anyasi, C. C., 2005, Influence of breweries effluent discharge on the microbiological and physicochemical quality of Ikpoba, River, Nigeria. African J. Biotech., 4(10):1062-1065.

Elliott, L. F. and Stevenson, F. J. 1977.Soils for Management of Organic Wastes and Wastewaters; SSSA: Madison, WI,

Gori, R.; Ferrini, F.; Nicese, FP.; Lubello, C. 2000, Effect of reclaimed wastewater on the growth and nutrient content of three landscape shrubs. J. Environ. Hortic., 18 (2), 108-114

Hati, K. M., Biswas, A. K., Bandyopadhyay, K., Mandal, K. G. and Misra, A. K., 2005, Influence of added spentwash on soil physical properties and yield of wheat under soybean-wheat system in Vertisol of central India. J. Plant Nutr. Soil Sci., 167: 584-590.

Hespanhol, I. 1990, Guidelines and integrated measures for public health protection in agricultural reuse systems. Aqua, 39 (4), 237-249.

Jamjoum, K. I. and Khattari, S. K., 1986, Effect of wastewater and sludge application on soil, corn plant composition and production in Zizia Region. Dirasat. 15 (11), 29-44.

Janeesh, A. C., 2008, Effect of coffee pulp effluent on growth, yield and quality of hybrid Napier grass. M. Sc. (Agri.) Thesis, Univ. Agric. Sci., Bengaluru, India.

K. Senthilraja*, P. Jothimani and G. Rajannan, 2013, Effect of brewery wastewater on growth and physiological changes in maize, sunflower and sesame crops. Intr $J$ Life Sci. Edu. Res., 1(1), pp. 36 - 42.

Kanagach and Ran, K. and Jayaratne, R., 2006, Utilization potential of brewery waste water sludge as an organic fertilizer. J. Inst. Brew. 112(2): 92-96.
Moazzam, A. S., Shahid, S., Omme, H. and Suriya, J., 2010, Irrigation of sorghum crop with waste stabilization pond effluent: growth and yield responses. Pakistan J. Bot., 42(3): 1665-1674.

Nwoko C. O., 2010, Evaluation of palm oil mill effluent to maize (Zea mays L.) crop yield, tissue nutrient content and residual soil chemical properties. Australian J. Crop Sci., 23 (1):56-62

Orhue, E. R., Osaigbovo, A. U., Osahon, O. and Dennis, E. 2005, Growth of Maize (Zea mays L.) and Changes in some chemical properties of an ultisol amended with brewery effluent. African. J. Biotech., 4(9): 973 - 978.

Quazzani, N., Bousseihaj, K. and Abbas, Y. 1996, Reuse of wastewater treated by infiltration percolation. Water Sci. Technol., 33 (10-11), 401-408.

Panse, V. G. and Sukhatme P. V., 1985, Statistical methods for agricultural workers, ICAR Publications, New Delhi. Pp. $1-21$.

Pathak, H., Joshi, H. C., Chaudhary, A., Chaudhary, R., Kalara, N. and Dwivedi, M. K., 1999, Soil amendments with distillery effluent for wheat and rice cultivation. Water, Air Soil Poll., 113: 133-140.

Papadopoulos, 1995, Wastewater Management for Agriculture Protection in the Near East Region; FAO, Regional Office for the Near East: Cairo, Egypt,; Tech. Bull.

Selim, M. M., 2008, Evaluation of the re-use of treated wastewater for irrigation. Acta Agron. Hungarica, 56(4):01610238.

Shang Ran, 2003, Influence of brewery wastewater irrigation on soil microflora. College of Resources and Environment, Shandong Agril. Univ. Taian, Shandong.

Srinivasamurthy, C. A., Bhaskar, S. and Balakrishna, A. N., 2008, Utilization 
of distillery spentwash for agricultural purpose. Technical bulletin, Pub. Department of Soil Science and Agricultural Chemistry, Univ. Agric. Sci., Bengaluru.

Sukanya, T. S. and Meli, S. S., 2003, Performance of rabi wheat under distillery effluent irrigation. Karnataka J. Agric. Sci., 16(3): 447450.

Tarchitsky, J., Golobati, Y., Keren, R. and Chen, Y., Wastewater effect on Montmorillonite suspensions and hydraulic properties of sandy soils. Soil Sci. Soc. American. J. 1999, 63 (3), 554-560.
Vijay Krishna, N., 2005, Effect of coffee pulp effluent on growth, yield and quality of rice, M.Sc. (Agri.) Thesis, Univ. Agric. Sci., Bengaluru. India.

Zalawadia, N. M. and Raman, S. J., 1994, Effect of distillery wastewater with graded fertilizer levels on sorghum yield and soil properties. Indian Soc. Soil Sci., 42: 575-579.

Zalawadia, N. M., Raman, S. and Patil, S. G., 1997, Influence of diluted spent wash of sugar industries application on yield and uptake by sugarcane and changes in soil properties. J. Indian Soc. Soil Sci., 45:767-769.

\section{How to cite this article:}

Manjunatha, B.N., S. Bhaskar and Shivaramu, H.S. 2017. Maize Response, Changes in Soil Available Nutrients and Microbial Population as Influenced by Brewery Wastewater Irrigation. Int.J.Curr.Microbiol.App.Sci. 6(4): 2712-2720. doi: http://dx.doi.org/10.20546/ijcmas.2017.604.315 